\title{
Anoa, dwarf buffalo from Sulawesi, Indonesia: Identification based on DNA barcode
}

\author{
DWI SENDI PRIYONO ${ }^{1, \nu}$, DEDY D. SOLIHIN ${ }^{1, \vartheta v}$, ACHMAD FARAJALLAH ${ }^{1}$, DIAH IRAWATI DWI ARINI ${ }^{2}$ \\ ${ }^{1}$ Department of Biology, Faculty of Mathematics and Natural Sciences, Institut Pertanian Bogor. J1. Raya Dramaga, Bogor 16680, West Java, Indonesia. \\ Tel./fax.: +62-251-8622642, `email: dwisendi92@yahoo.com, ${ }^{\vee *}$ dduryadi@yahoo.com \\ ${ }^{2}$ Anoa Breeding Center of Manado's, Center for Environment and Forestry Research and Development. J1. Raya Adipura, Manado 95119, North \\ Sulawesi, Indonesia
}

Manuscript received: 12 February 2018. Revision accepted: 4 October 2018.

\begin{abstract}
Priyono DS, Solihin DD, Farajallah A, Arini DID. 2018. Anoa, dwarf buffalo from Sulawesi, Indonesia: Identification based on DNA barcode. Biodiversitas 19: 1985-1992. Anoa is an endangered endemic species in Sulawesi. The controversial issue of anoa conservation until now is the taxonomic status of lowland and mountain anoa. This study aims to test the ability of DNA barcoding techniques to identify the taxonomy between mountain anoa and lowland anoa. A $681 \mathrm{bp}$ fragment of cytochrome oxidase subunit 1 (COI) gene was obtained and used to solve the molecular taxonomic problem and to resolve the phylogenetic relationships of the two types of anoa. Our results showed that the DNA barcode is useful in assigning the taxonomic position of anoa. In the phylogenetic tree, we found that the two types of anoa were in separate clades. We also found that based on the Kimura-2 parameter (K2P), the genetic distance between the two types of anoa showed higher values $(3.4 \%)$ than the threshold of the separating species level. We, therefore, proposed that the binomial nomenclature for both types of lowland and mountain anoa are respectively Bubalus depressicornis and Bubalus quarlesi. We suggest that the use of DNA barcode techniques in anoa taxonomic studies and their implementation will be useful in conservation management
\end{abstract}

Keywords: Anoa, COI, DNA barcoding, phylogenetic, molecular taxonomy

\section{INTRODUCTION}

Anoa is an endemic animal in Sulawesi Island. Anoa has a unique characteristic as compared to other Bovidae family members, in which anoa has a smaller size. The population of anoa in the wild continues to decline (Broto 2015). The main causes of anoa population decrease are due to poaching, conversions of forests into agricultural land, industrial areas and human habitats (Burton et al. 2005). The IUCN Redlist has categorized anoa as an endangered species since 1986, and The CITES included anoa in Appendix I since 1975, meaning that anoa is protected and cannot be traded. Various efforts in anoa conservation have been taken including captive breeding programs.

The success of species captive breeding program is not only supported by the large population but also on the information of the variation and genetic status of the species. Information about the genetic status of species in captivity provides records and guidelines in case of transportation between different breeding populations (Xie and Gipps 2012). If the genetic condition of the species is ignored, extinction will occur, and the most significant loss is the loss of germplasm of this endemic species in Indonesia. In addition to genetic information, one of the main problems in anoa conservation studies is the taxonomic status of anoa (Burton et al. 2005).

Until now, the status of anoa taxonomy is still much debated. Anoa is classified by habitat and some of its morphological characters, such as lowland anoa and mountain anoa. The varying number of chromosomes in these two types of anoa $(2 \mathrm{~N}=44,45,47,48)$ shows phylogenetic and taxonomic problems (Schreiber et al. 1993). At the subgenus level, the identification of the skull (Groves 1969), the hemoglobin $\alpha$ amino acid sequence analysis (Kakoi et al. 1994), and the identification of cytochrome b (Tanaka et al. 1996) suggest that both types of anoa are categorized under the anoa subgenus. However, nuclear DNA analysis (cytochrome P450 aromatase partial sequence and lactoferrin gene) shows that lowland anoa is closer to the genus of Boselaphus, not Bubalus (Pitra et al. 1997). At the species level, the anoa taxonomic position also encounters problems. A few researchers (Lydekker 1905; Dolan 1965) claimed that the anoa is divided into two species, Bubalus depressicornis, and Bubalus quarlesi, or as a species with three subspecies which is Bubalus $d$. depressicornis, Bubalus $d$. quarlesi, and Bubalus $d$. fergusoni. Schreiber et al. (1993) conducted allozyme analysis on 25 anoas in European zoos. The allozyme distance formed is between $\mathrm{D}=0.0206$ to $\mathrm{D}=0.0505$. The range of allozyme distance is more likely to indicate a separation of subspecies level (Nei 1987). Hartl et al. (1988) previously also analyzed the greater distance of allozyme ( $D=0.1389$ to $D=0.7621$ ) to classify many species in Bovini. Based on the taxonomic ambiguities that appear at the subgenus, species and subspecies levels, further research is needed to diagnose taxonomy of anoa using a more robust marker, such as mitochondrial DNA markers (Solihin 1994).

One of the most widely used mitochondrial DNA 
markers in identifying taxonomic units is the cytochrome c oxidase subunit I (COI) gene marker. The used of COI gene as DNA barcoding marker has been declared as an accurate tool in the identification and phylogenetic inferences of a species (Hebert et al. 2003). Some recent studies in Bovidae family member show that the use of DNA barcode has also solved various problems in determining a more appropriate taxonomic unit (Yang et al. 2013; Barmann et al. 2013).

Certainty in determining taxonomic units is necessary to support the success of breeding in conservation. Valuable data from genetic approaches such as genetic information, evolution, and phylogenetics are required for species monitoring and conservation management (Schwartz et al. 2007). In such cases, conservation efforts for 'endangered species' may be misdirected concerning the goal of protecting biodiversity. This study aims to apply
DNA barcode techniques and to identify genetic differences and taxonomic status of lowland anoa and mountain anoa based on the mtDNA COI gene. These results are used as a baseline for future planning and management of anoa conservation management. $\square$

\section{MATERIALS AND METHODS}

\section{Sample collection}

A total of 10 samples of anoa was obtained, consisting of 5 lowland anoa and five mountain anoa. Lowland anoa were obtained from Palu $(n=2)$, Gorontalo $(n=1)$, Bolaang Mongondow $(n=1)$, and Toli-toli $(n=1)$. Mountain anoa was obtained from Sidenreng Rappang $(n=2)$, Luwu $(n=2)$ and Seko $(\mathrm{n}=1)$ (Figure 1).

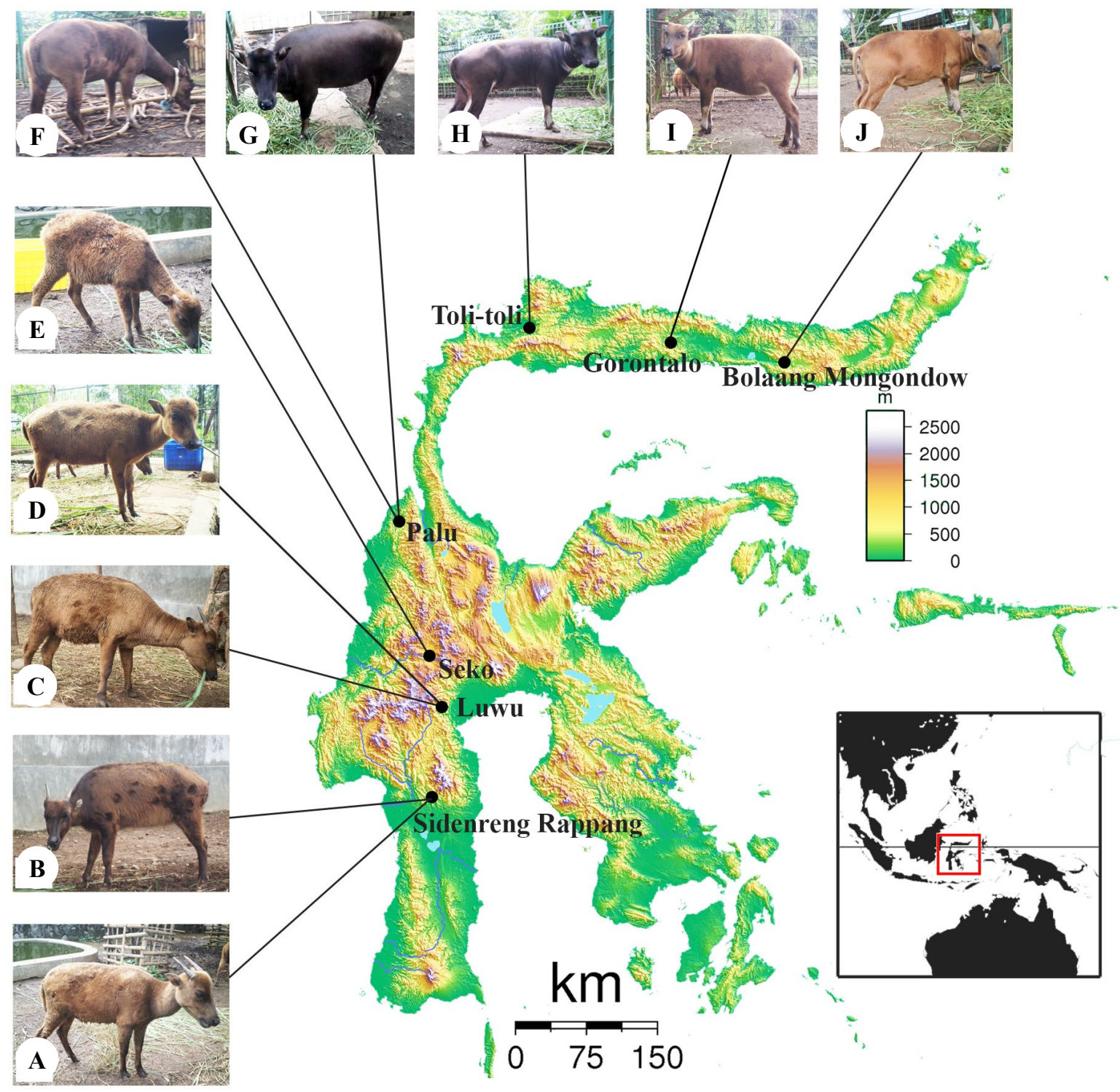

Figure 1. The location of origin of anoa used in this study: A. Ambo Sidenreng, B. Indo Sidenreng, C. Indo Luwu, D. Ambo Luwu, E. Indo Seko, F. Denok, G. Manis, H. Rambo, I. Rita, J. Rocky 


\section{DNA isolation, PCR amplification, DNA sequencing}

Total genomic DNA from blood was extracted by using DNeasy Blood \& Tissue Kit (Qiagen) following manufacturer protocols with some modifications of the original protocol to improve the yield and quality of the extracted DNA. Modification of the protocol consisted of adding proteinase-k to $40 \mu \mathrm{L}$ and the length of the incubation time was overnight after addition of ethanol. The COI gene was amplified using the Polymerase chain reaction (PCR) technique. PCR reaction was carried out with a total mixture of $25 \mu \mathrm{L}$, with the composition of $1 \mathrm{x}$ PCR buffer (Promega), GC 1x enhancer, $0.2 \mathrm{mM}$ dNTP (Qiagen), 10pg DNA template, $0.02 \mathrm{U} / \mu \mathrm{L}$ Taq polymerase (BioLabs, England), $0.02 \mu \mathrm{M}$ of each primer (COI B_Depress (F)-5'GGCACCCTGTATTTGCTGTT3', COI B_Depress (R)-5'GCCGGAACATCATACTTCGT3'). The amplification condition consisted an initial step for $5 \mathrm{~min}$ at $94^{\circ} \mathrm{C}$ followed by 35 cycles of 45 seconds at $94^{\circ} \mathrm{C}, 45$ seconds at $53.4^{\circ} \mathrm{C}$, and $6 \mathrm{~min}$ at $72^{\circ} \mathrm{C}$, followed by a final incubation at $72^{\circ} \mathrm{C}$ for $10 \mathrm{~min}$. The $1.2 \%$ agarose gel was used to visualize PCR amplicons. PCR products were then sent for sequencing using an $\mathrm{ABI} 3730$ sequencing machine provided by the First Base Laboratories (Singapore).

\section{Data analysis}

Alignment and sequence visualization was carried out using ClustalW on MEGA ver. 6 (Tamura et al. 2013) and manually checked in the BIOEDIT program ver 7.0.9 (Hall 1999). The final alignment consisting of 681 base pairs was then verified into the Barcode of Life Data System (BoLD System) (www.barcodinglife.org) to ensure the identity of the samples and to test homology with the available sequences in GenBank. Conspecific COI sequences of lowland anoa species that have been obtained from GenBank with the accession number of EF536351, NC020615 (Hassanin et al. 2012) were also included in the analysis and compared with the aligned sequences. The sequence was derived from anoa that the origin of the anoa was unknown, and the individual was housed at the Ménagerie du Jardin des Plantes of the Museum national d'Histoire Naturelle of Paris (Hassanin, pers. comm.). The Kimura-2 Parameters method (K2P) was used to calculate intra-and inter-species genetic distances (Kimura 1980). In a case for overlooked species, we employed a sequence divergence of $2,5 \%$ as a screening threshold for mammals as recommended by Tobe et al. (2010). Phylogenetic trees were constructed with a combination of three models: Maximum Likelihood in the Treefinder (Jobb et al. 2004) with 1000 replications, Bayesian analysis using MrBayes 3.1.2 with Markov Chain Monte Carlo (MCMC) 10 million (Huelsenbeck and Ronquist 2001) and 2500 burn-in, and Neighbour Joining using Mega 6 (Tamura et al. 2013) with 1000 bootstrap replicates.

Currently, the anoa is in captivity of Anoa Breeding Center (ABC), Center for Environment and Forestry Research and Development (BP2LHK), Manado, North Sulawesi, Indonesia, and Conservation Center of Bontomarannu Education Park (BEP), Gowa, South Sulawesi, Indonesia. As much as $5-10 \mathrm{~mL}$ of blood was taken from the jugular vein from each specimen using the EDTA vacutainer tube and then stored at $-40^{\circ} \mathrm{C}$.

\section{RESULTS AND DISCUSSION}

\section{BoLD identification}

The $681 \mathrm{bp}$ sequence was obtained and then analyzed using the BoLD system to ensure the conformity of samples with available databases (Table 3 ). The similarity of the lowland anoa in this study with those of anoa in BoLD system showed high similarity, ranged between 97.64-98.08\%. Whereas for mountain anoa case, the highest similarity was not with those of lowland anoa, but with the Buffalo group (Bubalus bubalis) with the similarity level ranging from $97.96-97.22 \%$ or divergence ranging from $2.04-2.78 \%$. The high similarity between the mountain anoa and the buffalo (Bubalus bubalis and Bubalus carabanesis) in BoLD system perhaps due to misidentification occurred in the BOLD system as the range of available base in genebank database (query cover) did not reach the base length of anoa to be identified. The previous case of BoLD misidentification has also been described, especially in sequence coverage for identification (Kwong et al. 2012). On the other hand, a previous DNA barcode study, buffalo groups had huge divergence that separate buffalo groups and buffalo group classification is still a matter of debate (Cai et al. 2011, Kochar et al. 2002). To clarify this case, it is important to reconstruct a phylogenetic tree by including buffalo group.

\section{Nucleotide variations}

The concern when using mitochondrial DNA amplification was the amplification of "COI-like sequences" or nuclear pseudogenes of mitochondrial origin (numt) (Buhay 2009). To confirm this sequence was utterly originated from mitochondrial DNA COI gene, we conducted several investigations. One of the numt characters of numt is the presence of insertion and deletion in DNA sequences (NUMTs, Bensasson et al. 2001). However, the results of anoa COI gene alignment in this study found no insertion-deletion (indel) event. Also, to ensure in filtering numt, we carefully examined heterozygosity of peak sequences (Buhay 2009), and the obtained sequence did not contain any overlapping peaks. So it could be ascertained that sequences used in the DNA barcode technique in this study are COI genes in the mitochondrial DNA.

Variations in base transitional mutations in COI genes were occurring more than transversions. In all anoa samples, the number of transition mutations sites was 33, while transversion mutation sites were 14 or with ratio 2.3 (Table 2). The number of these transition mutations is also found in mitochondrial DNA as reported Lakra et al. (2009). The results of their research suggested that the ratio of transition with transversion were 2.0 in the COI gene. Although the phenomenon of transition bias was a few little understood, it was suggested that there are two contributing factors. First, spontaneous mutations rate involving transitional mutations was much greater than transversion mutations. Second, purification selection affected the transition bias because transitional mutations are more likely to be synonymous than transverse mutations (Beckenbach et al. 1990). COI anoa gene 
sequence showed less GC base composition than AT base composition. GC base compositions range from 45.645.8\%. In many cases in mammals, GC base composition was $<50 \%$ (Martin 1995) and also found in other Bovidae species (Hassanin et al. 2009). Each taxon had different GC base composition but almost all show base composition $<50 \%$, for example in other mammal groups: Bos taurus $33.1 \%$, Homo sapiens 47.2\%, Mus musculus 26.6\%, (Perna and Kocher 1995). The difference in GC base composition probably related to metabolic physiology.

Closed examination on the aligned DNA sequences of 12 anoa samples ( 2 additional from GenBank) showed that there are 47 variable sites and 634 conserved sites (Table 3 ). Of all the variable sites, there were unique sites that found specifically for each type of anoa. For example, lowland anoa has base $A$ at position 60 , while mountain anoa only has base $\mathrm{G}$. These unique sites are at the position of $24,30,43,60$, and 384 , with nucleotide T, A, G, A, and $G$ recorded for the lowland anoa, while $G, C, T, G$, and A for the mountain anoa. These unique nucleotide sites can be used as diagnostic characters for discriminating the lowland and mountain anoa. Character-based identification method (in this case, nucleotide DNA) was one of the alternatives proposed in identification because they retain lost information inherently in distance approach (Kelly et al. 2007; Waugh et al. 2007). Such characters can be regarded as a simple diagnostic nucleotide, sND). Sarkar et al. (2002) used this term to describe the diagnostic character that consists of several shared nucleotide sites. $\mathrm{ND}$, or character attribute (CA) in terms of Sarkar et al. (2002), has been widely applied in molecular identification studies in species (Wong et al. 2008; Wong et al. 2009; Kelly et al. 2007; Rach et al. 2008). In this study, the potential use of ND is for identification of anoa using COI barcode sequence, especially in conservation forensics. This identification method can also be a quick identification alternative for both types of anoa, providing the presence of ambiguity in the identification of distancebased on BoLD. $\square$

\section{Genetic distance}

The genetic distance (Table 4) within and between lowland and mountain anoa (including GenBank sequences) was calculated based on the Kimura-2 parameter (K2P). The lowest genetic distance for all specimens was 0.00 , while the highest genetic distance was 0.039 (Table 4). Interspecific genetic ranges between the two types of anoa ranged from the lowest $(0.030)$ to the highest (0.039) with an average of $3.4 \%$. The average interspecific genetic distance was lower than previous DNA barcode study in the Bovidae group, i.e., 6.3\% (Cai et al. 2010). Cai et al. (2010) indicated that the high mean of genetic distance in the study $(6.3 \%)$ was due to the high maximum genetic distance in the Bubalus bubalis group $(12.44 \%)$. The classification of buffalo that consists of 4 groups as a single species or not, is still being debated (Kochar et al. 2002). The problem of buffalo classification may because of ambiguity occurs when identifying mountain anoa using the BoLD system.
Table 1. The top three BoLD identification result of anoa species with respective percentage similarity

\begin{tabular}{|c|c|c|c|}
\hline $\begin{array}{l}\text { Name of } \\
\text { specimens }\end{array}$ & $\begin{array}{l}\text { Putative } \\
\text { species } \\
\text { identification }\end{array}$ & $\begin{array}{l}\text { Top three BOLD } \\
\text { identification result }\end{array}$ & $\begin{array}{c}\text { Similarity } \\
(\%)\end{array}$ \\
\hline \multirow[t]{3}{*}{ Rambo } & \multirow[t]{3}{*}{ Lowland anoa } & B. depressicornis & 98.08 \\
\hline & & B. bubalis & 97.22 \\
\hline & & B. bubalis bubalis & 97.17 \\
\hline \multirow[t]{3}{*}{ Rita } & \multirow[t]{3}{*}{ Lowland anoa } & B. depressicornis & 98.08 \\
\hline & & B. bubalis & 97.41 \\
\hline & & B. bubalis bubalis & 97.02 \\
\hline \multirow{3}{*}{ Manis } & \multirow[t]{3}{*}{ Lowland anoa } & B. depressicornis & 98.08 \\
\hline & & B. bubalis & 97.41 \\
\hline & & B. bubalis bubalis & 97.02 \\
\hline \multirow{3}{*}{ Denok } & \multirow{3}{*}{ Lowland anoa } & B. depressicornis & 97.64 \\
\hline & & B. bubalis & 97.59 \\
\hline & & B. carabanesis $\square$ & 97.16 \\
\hline \multirow[t]{3}{*}{ Rocky } & \multirow[t]{3}{*}{ Lowland anoa } & B. depressicornis & 98.82 \\
\hline & & B. bubalis & 97.96 \\
\hline & & B. bubalis bubalis & 97.77 \\
\hline \multirow[t]{3}{*}{ Ambo Sidenreng } & \multirow[t]{3}{*}{ Mountain anoa } & B. bubalis & 97.78 \\
\hline & & B. carabanesis $\square$ & 97.4 \\
\hline & & B. depressicornis & 96.76 \\
\hline \multirow[t]{3}{*}{ Indo Seko } & \multirow[t]{3}{*}{ Mountain anoa } & B. bubalis & 97.22 \\
\hline & & B. carabanesis $\square$ & 96.93 \\
\hline & & B. depressicornis & 96.61 \\
\hline \multirow[t]{3}{*}{ Ambo Luwu } & \multirow[t]{3}{*}{ Mountain anoa } & B. bubalis & 97.78 \\
\hline & & B. carabanesis $\square$ & 97.4 \\
\hline & & B. depressicornis & 97.05 \\
\hline \multirow[t]{3}{*}{ Indo Luwu } & Mountain anoa & B. bubalis & 97.78 \\
\hline & & B. carabanesis $\square$ & 97.16 \\
\hline & & B. depressicornis & 96.61 \\
\hline Indo Sidenreng & Mountain anoa & B. bubalis & 97.96 \\
\hline & & B. carabanesis $\square$ & 97.4 \\
\hline & & B. depressicornis & 97.05 \\
\hline Rambo & Lowland anoa & B. depressicornis & 98.08 \\
\hline & & B. bubalis & 97.22 \\
\hline & & B. bubalis bubalis & 97.17 \\
\hline Rita & Lowland anoa & B. depressicornis & 98.08 \\
\hline & & B. bubalis & 97.41 \\
\hline & & B. bubalis bubalis & 97.02 \\
\hline Manis & Lowland anoa & B. depressicornis & 98.08 \\
\hline & & B. bubalis & 97.41 \\
\hline & & B. bubalis bubalis & 97.02 \\
\hline Denok & Lowland anoa & B. depressicornis & 97.64 \\
\hline & & B. bubalis & 97.59 \\
\hline & & B. carabanesis $\square$ & 97.16 \\
\hline Rocky & Lowland anoa & B. depressicornis & 98.82 \\
\hline & & B. bubalis & 97.96 \\
\hline & & B. bubalis bubalis & 97.77 \\
\hline Ambo Sidenreng & Mountain anoa & B. bubalis & 97.78 \\
\hline & & B. carabanesis $\square$ & 97.4 \\
\hline & & B. depressicornis & 96.76 \\
\hline Indo Seko & Mountain anoa & B. bubalis & 97.22 \\
\hline & & B. carabanesis $\square$ & 96.93 \\
\hline & & B. depressicornis & 96.61 \\
\hline Ambo Luwu & Mountain anoa & B. bubalis & 97.78 \\
\hline & & B. carabanesis $\square$ & 97.4 \\
\hline & & B. depressicornis & 97.05 \\
\hline Indo Luwu & Mountain anoa & B. bubalis & 97.78 \\
\hline & & B. carabanesis $\square$ & 97.16 \\
\hline & & B. depressicornis & 96.61 \\
\hline Indo Sidenreng & Mountain anoa & B. bubalis & 97.96 \\
\hline & & B. carabanesis $\square$ & 97.4 \\
\hline & & B. depressicornis & 97.05 \\
\hline
\end{tabular}


Table 2. Nucleotides variations, mutations types, and base composition of COI gene

\begin{tabular}{|c|c|c|c|c|c|c|c|c|}
\hline \multirow{2}{*}{ Species } & \multirow{2}{*}{ Conserved sites } & \multicolumn{2}{|c|}{ Variation } & \multirow{2}{*}{ Variable sites } & \multirow{2}{*}{ si } & \multirow{2}{*}{ sv } & \multicolumn{2}{|c|}{ Base composition (\%) } \\
\hline & & $\mathbf{P i}$ & $\mathbf{s}$ & & & & AT & GC \\
\hline \multicolumn{9}{|l|}{$\overline{\text { Gen COI }}$} \\
\hline Bubalus depressicornis & 655 & 18 & 8 & 26 & 19 & 7 & 54,2 & 45,8 \\
\hline Bubalus quarlessi & 658 & 7 & 16 & 23 & 19 & 4 & 54,4 & 45,6 \\
\hline All specimen & 634 & 36 & 11 & 47 & 33 & 14 & 54,4 & 45,6 \\
\hline
\end{tabular}

Note: Pi: Parsimony-informative site, s: singleton site, si: transition pair, sv: transversi pair dan R: ratio of number of transitions to number of transversions

Table 3. Variable sites in anoa based on COI gene. Bold indicates the unique nucleotide variations of each anoa type. $\square$

\begin{tabular}{|c|c|c|c|c|c|c|c|c|c|c|c|c|c|c|c|c|c|c|c|c|c|c|}
\hline \multirow{4}{*}{ Specimen } & \multicolumn{22}{|c|}{ Variable sites } \\
\hline & & & & & & & & & & & & & & & & 1 & 1 & 1 & 1 & 1 & 2 & 2 \\
\hline & 2 & 2 & 2 & 3 & 3 & 3 & 4 & 4 & 4 & 4 & 4 & 6 & 6 & 8 & 9 & 1 & 2 & 2 & 4 & 5 & 0 & 0 \\
\hline & 1 & 4 & 9 & $\mathbf{0}$ & 2 & 5 & 2 & 3 & 4 & 6 & 7 & $\mathbf{0}$ & 3 & 1 & 0 & 4 & 0 & 4 & 7 & 9 & 4 & 7 \\
\hline B.depreesicornis_Rambo & $\mathrm{T}$ & $T$ & $\mathrm{G}$ & $\mathbf{A}$ & $\mathrm{C}$ & $\mathrm{G}$ & $\mathrm{A}$ & $\mathbf{G}$ & $\mathrm{G}$ & $\mathrm{A}$ & $\mathrm{C}$ & $\mathbf{A}$ & $\mathrm{G}$ & $\mathrm{T}$ & $\mathrm{G}$ & $\mathrm{G}$ & $\mathrm{C}$ & $\mathrm{G}$ & $\mathrm{A}$ & $\mathrm{C}$ & $\mathrm{T}$ & $\mathrm{T}$ \\
\hline B.depreesicornis_Rita & . & . & . & . & . & . & . & . & A & . & . & . & . & . & $\mathrm{T}$ & . & . & . & . & . & . & . \\
\hline B.depreesicornis_Rocky & . & . & . & . & & . & . & . & . & 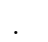 & . & . & . & . & . & $\mathrm{C}$ & . & . & . & . & $\mathrm{C}$ & . \\
\hline B.depreesicornis Manis & . & . & . & . & . & $\mathrm{T}$ & . & . & . & . & 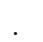 & . & . & . & . & . & . & $\mathrm{A}$ & . & . & $\mathrm{C}$ & . \\
\hline B.depreesicornis_Denok & . & . & $\mathrm{T}$ & . & G & $\mathrm{T}$ & 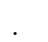 & . & A & G & & . & . & . & 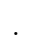 & $\mathrm{C}$ & 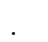 & $\mathrm{A}$ & . & . & $\mathrm{C}$ & . \\
\hline B.quarlessi AmboSidenreng & G & G & $\mathrm{T}$ & $\mathbf{C}$ & $\mathrm{G}$ & & . & $\mathbf{T}$ & A & G & $\mathrm{A}$ & G & $\mathrm{A}$ & . & 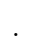 & $\mathrm{C}$ & $\mathrm{T}$ & A & G & & $\mathrm{C}$ & . \\
\hline B.depreesicornis IndoSeko & $\mathrm{G}$ & $\mathbf{G}$ & $\mathrm{T}$ & $\mathbf{C}$ & $\mathrm{G}$ & & ${ }^{\circ}$ & $\mathbf{T}$ & A & G & $\mathrm{A}$ & G & $\mathrm{A}$ & . & . & $\mathrm{C}$ & $\mathrm{T}$ & $\mathrm{A}$ & G & . & $\mathrm{C}$ & . \\
\hline B.depreesicornis AmboLuwu & . & G & $\mathrm{T}$ & $\mathbf{C}$ & 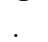 & & $\mathrm{T}$ & $\mathbf{T}$ & . & $\mathrm{G}$ & $\mathrm{A}$ & G & $\mathrm{A}$ & . & ${ }^{\circ}$ & $\mathrm{C}$ & $\mathrm{T}$ & $\mathrm{A}$ & $\mathrm{G}$ & . & $\mathrm{C}$ & . \\
\hline B.depreesicornis IndoLuwu & $\cdot$ & $\mathbf{G}$ & $\mathrm{T}$ & C & $\mathrm{G}$ & & $\mathrm{T}$ & $\mathbf{T}$ & A & $\mathrm{G}$ & G & G & $\mathrm{A}$ & . & & $\mathrm{C}$ & $\mathrm{T}$ & $\mathrm{A}$ & $\mathrm{G}$ & . & $\mathrm{C}$ & . \\
\hline B.depreesicornis_IndoSidenreng & & $\mathbf{G}$ & $\mathrm{C}$ & $\mathbf{C}$ & & & $\mathrm{T}$ & $\mathbf{T}$ & & G & A & $\mathbf{G}$ & & $\mathrm{C}$ & & $\mathrm{C}$ & & & & $\mathrm{T}$ & $\mathrm{C}$ & $\mathrm{C}$ \\
\hline
\end{tabular}

\begin{tabular}{|c|c|c|c|c|c|c|c|c|c|c|c|c|c|c|c|c|c|c|c|c|c|}
\hline \multirow{4}{*}{ Specimen } & \multicolumn{21}{|c|}{ Variable sites } \\
\hline & 2 & 2 & 2 & 2 & 2 & 2 & 2 & 2 & 3 & 3 & 3 & 4 & 4 & 4 & 4 & 4 & 5 & 5 & 5 & 5 & 6 \\
\hline & 0 & 1 & 2 & 3 & 3 & 4 & 5 & 8 & 6 & 8 & 8 & 1 & 4 & 5 & 7 & 9 & 3 & 5 & 8 & 9 & 7 \\
\hline & 8 & 0 & 2 & 1 & 7 & 6 & 2 & 5 & 0 & 1 & 4 & 4 & 4 & 9 & 4 & 2 & 4 & 9 & 3 & 1 & 3 \\
\hline B.depreesicornis_Rambo & G & $\mathrm{A}$ & $\mathrm{T}$ & G & $\mathrm{C}$ & G & $\mathrm{T}$ & $\mathrm{G}$ & $\mathrm{C}$ & $\mathrm{A}$ & $\mathbf{G}$ & $\mathrm{A}$ & $\mathrm{T}$ & $\mathrm{T}$ & $\mathrm{C}$ & $\mathrm{T}$ & G & $\mathrm{C}$ & $\mathrm{C}$ & $\mathrm{T}$ & $\mathrm{C}$ \\
\hline B.depreesicornis_Rita & $\mathrm{C}$ & . & . & . & 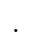 & & . & . & . & G & . & . & . & . & . & . & . & . & . & . & . \\
\hline B.depreesicornis_Rocky & $\mathrm{C}$ & . & $\mathrm{C}$ & $\mathrm{A}$ & & & . & $\mathrm{A}$ & . & G & . & . & . & . & $\mathrm{T}$ & $\mathrm{C}$ & . & . & $\mathrm{T}$ & $\mathrm{C}$ & . \\
\hline B.depreesicornis_Manis & . & . & . & . & $\mathrm{T}$ & & . & $\mathrm{A}$ & . & $\mathrm{G}$ & . & $\mathrm{T}$ & . & . & $\mathrm{T}$ & $\mathrm{C}$ & A & . &. & . & . \\
\hline B.depreesicornis_Denok & . & . & . & . & $\mathrm{T}$ & . & . & A & . & $\mathrm{G}$ & . & $\mathrm{T}$ & . & . & $\mathrm{T}$ & $\mathrm{C}$ & A & . & . & . & . \\
\hline B.quarlessi_AmboSidenreng & $\mathrm{C}$ & . & . & A & & A & $\mathrm{C}$ & A & . & . & $\mathbf{A}$ & . & $\mathrm{C}$ & . & $\mathrm{T}$ & $\mathrm{C}$ & . & . & . & . & . \\
\hline B.depreesicornis_IndoSeko & $\mathrm{C}$ & . & . & A & & & $\mathrm{C}$ & A & . & $\mathrm{G}$ & $\mathbf{A}$ & . & $\mathrm{C}$ & $\mathrm{C}$ & $\mathrm{T}$ & . & . & $\mathrm{T}$ & . & . & . \\
\hline B.depreesicornis_AmboLuwu & $\mathrm{C}$ & . & . & A & & A & $\mathrm{C}$ & A & . & . & $\mathbf{A}$ & . & $\mathrm{C}$ & . & $\mathrm{T}$ & $\mathrm{C}$ & . & . & . & . & . \\
\hline B.depreesicornis_IndoLuwu & $\mathrm{C}$ & . & . & A & & A & $\mathrm{C}$ & A & . & . & $\mathbf{A}$ & . & $\mathrm{C}$ & . & $\mathrm{T}$ & $\mathrm{C}$ & . & . & . & . & A \\
\hline B.depreesicornis_IndoSidenreng & $\mathrm{C}$ & $\mathrm{G}$ & & $\mathrm{A}$ & & & & A & $\mathrm{T}$ & G & $\mathbf{A}$ & & & & $\mathrm{T}$ & $\mathrm{C}$ & & & & & A \\
\hline
\end{tabular}

Table 4. Genetic distance in mountain and lowland anoa based on K2P method. Bold indicates the high genetic distances between two type of anoa. $\square$

\begin{tabular}{|c|c|c|c|c|c|c|c|c|c|c|c|c|c|}
\hline & Specimen & 1 & 2 & 3 & 4 & 5 & 6 & 7 & 8 & 9 & 10 & 11 & 12 \\
\hline 1 & EF536351_B.depress & & & & & & & & & & & & \\
\hline 2 & NC020615_B.depres & 0.000 & & & & & & & & & & & \\
\hline 3 & B.depress_Rambo & 0.019 & 0.019 & & & & & & & & & & \\
\hline 4 & B.depress_Rita & 0.019 & 0.019 & 0.006 & & & & & & & & & \\
\hline 5 & B.depress_Rocky & 0.012 & 0.012 & 0.016 & 0.016 & & & & & & & & \\
\hline 6 & B.depress_Manis & 0.019 & 0.019 & 0.015 & 0.018 & 0.016 & & & & & & & \\
\hline 7 & B.depress_Denok & 0.024 & 0.024 & 0.022 & 0.022 & 0.021 & 0.007 & & & & & & \\
\hline 8 & B.quarles_AmboSidenreng & 0.033 & 0.033 & 0.038 & 0.038 & 0.033 & 0.038 & 0.030 & & & & & \\
\hline 9 & B.quarles_IndoSeko & 0.035 & 0.035 & 0.039 & 0.036 & 0.035 & 0.039 & 0.032 & 0.007 & & & & \\
\hline 10 & B.quarles_AmboLuwu & 0.030 & 0.030 & 0.035 & 0.038 & 0.030 & 0.035 & 0.033 & 0.006 & 0.013 & & & \\
\hline 11 & B.quarles IndoLuwu & 0.035 & 0.035 & 0.039 & 0.039 & 0.035 & 0.039 & 0.032 & 0.006 & 0.013 & 0.006 & & \\
\hline 12 & B.quarles IndoSidenreng & 0.030 & 0.030 & 0.035 & 0.035 & 0.027 & 0.035 & 0.035 & 0.028 & 0.029 & 0.022 & 0.026 & \\
\hline
\end{tabular}


Table 5. Intra-species and interspecies genetic distances in mountain and lowland anoa based on the K2P method

\begin{tabular}{lcc}
\hline Genetic distance & $\begin{array}{c}\text { Bubalus } \\
\text { depressicornis }\end{array}$ & $\begin{array}{c}\text { Bubalus } \\
\text { quarlessi }\end{array}$ \\
\hline Gen COI & 0.0 & 0.6 \\
Minimum intraspecies distance & 2.9 & 2.6 \\
Maximum intraspecies distance & 1.6 & 1.6 \\
Average of intraspecies distance & \multicolumn{2}{c}{3.4} \\
Average of interspecies distance $\square$ & & \\
\hline
\end{tabular}

Interesting result was found in genetic distance between mountain and lowland anoa. The genetic distance between these two species of anoa was $3.4 \%$ (Table 5). This genetic distance is higher than $3 \%$ threshold for species-level separation as mentioned by Hebert et al. (2003) in the study of DNA barcodes, and also more than $2.5 \%$ threshold of species-level separation for mammals according to Tobe et al. (2010) for COI gene. Based on these higher distance, it was suggested that both types of anoa have high genetic differences and may have been even two different species.

\section{Reconstruction of phylogenetic trees}

A phylogenetic tree was reconstructed by including domestic buffaloes to clarify the relationship between anoa and domestic buffaloes regarding the ambiguity of BoLD results, as well as Boselaphus tragocamelus. Previous research by Pitra et al. (1997) suggested that anoa is included within the Boselaphus group based on the nuclear gene sequence. The phylogenetic reconstruction showed that there are three main monophyletic clades (Figure 2). Clade I consists of lowland anoa, Clade II consists of mountain anoa, and Clade III consists of domestic buffalo. Finally, results of this phylogenetic analysis have successfully clarified that the mountain anoa was separated from buffalo group and closer to the lowland anoa. In addition, the anoa was included within the Bubalus group, not within the Boselaphus group. These results support previous studies on grouping anoa into Bubalus group (Kakoi et al. 1994; Schreiber et al. 1995; Burton et al. 2005). The branch supports between groups of anoa had a high percentage of posterior probability, bootstrap, and a high ML (1/100/100), thus supports the separation and polarity of two types anoa into different groups. These results were similar to the results of genetic distance analysis. A genetic richness that existed in anoa species had previously been reported by Sugiri and Hidayat (1996) who suggested that there were more than two species in anoa based on karyotype of wild anoa from mountains of Central Sulawesi. Three individuals from one region have a chromosome number of $2 \mathrm{n}=46$, yet another anoa had $2 \mathrm{n}=$ 44. Recent research (Rozzi 2017) on fossil analysis suggested there were three species of anoa, $B$. grovesi, $B$. depressicornis and B. quarlesi.

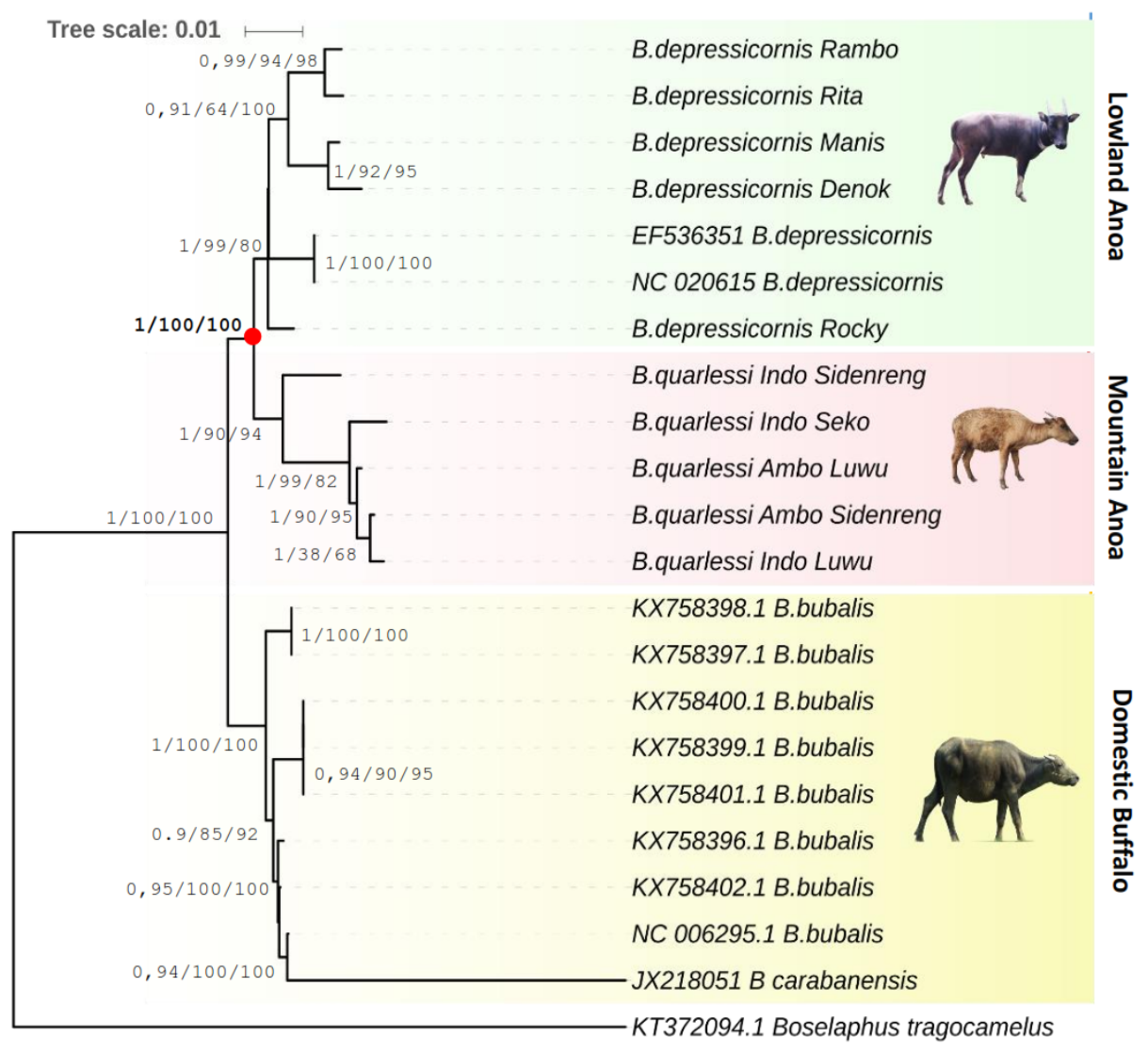

Figure 2. Reconstruction of anoa phylogenetic tree with the addition of domestic buffaloes, and Boselaphus tragocamelus from Genbank (node value from left-right: BA probability, NJ bootstrap, and ML percentage) 
The endemicity of Anoa in Sulawesi island may be the results of adaptive radiation process, a process by which organisms diversify rapidly from ancestor species into many new forms. This may be implied by the results of our genetic study that discriminate anoa and the buffalo. Other similar studies include an examination of seven Sulawesi black ape morphotypes (Cynopithecus spp., Fooden 1969), tarsiers (Tarsius spp., Merker et al. 2010), birds (White and Bruce 1986), insects (Knight and Holloway 1990), gastropods (Glaubrecht and Rintelen 2008), and frogs (Setiadi et al. 2011). Such studies have provided examples and cases that animals have undergone adaptive radiation into various forms of species in Sulawesi.

There are several genetic information and molecular taxonomy of anoa that have been identified in this study that can become baseline information for further studies. Conservation management of anoa can be carried out in captive breeding with the aim is to increase quantity and quality of breeding population/individual by correctly grouping animal units according to their species and genetic entity, as well as developing cryopreservation of germplasm for its sustainability. A broader genetic study is still needed to be carried out, especially by including more samples and the use of the more advanced molecular technique.

\section{ACKNOWLEDGEMENTS}

We acknowledged Ministry of Research, Technology and Higher Education of the Republic of Indonesia for providing research funding through Master Program of Education Leading to Doctoral Degree for Excellent Graduates (PMDSU) program, as well as to the staff and researchers at Anoa Breeding Center, Manado, Indonesia and Bontomarannu Education Park, Gowa, Indonesia. $\square$

\section{REFERENCES}

Barmann EV, Gertrud ER, Gert W. 2013. A revised phylogeny of Antilopini (Bovidae; Artiodactyla) using combined mitochondrial and nuclear genes. Mol Phylogenet Evol 67: 484-493.

Beckenbach AT, Thomas WK, Sohrabi H. 1990. Intraspecific sequence variation in the mitochondrial genome of rainbow trout (Oncorhynchus mykiss). Genome 33: 13-15.

Bensasson D, Zhang DX, Hartl DL, Hewitt GM. Mitochondrial pseudogenes: evolution's misplaced witnesses. 2001 Trends Ecol Evol 16 (6): 314-321.

Broto BW. 2015. Struktur dan komposisi vegetasi habitat anoa (Bubalus spp.) di Hutan Lindung Pegunungan Mekongga, Kolaka, Sulawes Tenggara. Pros Sem Nas Masy Biodiv Indon 1 (3): 615-620.

Buhay JE. 2009. "COI-like" Sequences Are Becoming Problematic in Molecular Systematic and DNA Barcoding Studies. J Crustacean Biol 29 (1): 96-110.

Burton JA, Hedges S, Mustari AH. 2005. The taxonomic status, distribution, and conservation of the lowland anoa Bubalus depressicornis and mountain anoa Bubalus quarlesi. Mammal Rev 35: $25-50$.

Cai Y, Zhang L, Shen F, Zhang W, Hou R. 2011. DNA barcoding of 18 species of Bovidae. Chinese Sci Bull 56 (2): 164-168.

Dolan JM. 1965. Breeding of the lowland anoa, Bubalus (Anoa) $d$. depressicornis in the San Diego Zoological Garden. Zeitschrift fur Saugetierkunde 30: 241-248.
Fooden J. 1969. Taxonomy and evolution of the monkeys of Celebes. Karger, Switzerland.

Glaubrecht M, Rintelen TV. 2008. The species flocks of lacustrine gastropods: Tylomelania on Sulawesi as models in speciation and adaptive radiation. Hydrobiologia 615 (1): 181-199.

Groves CP. 1969. Systematic of the Anoa (Mammalia, Bovidae). Beaufortia 17 (223): 1-11.

Hartl G, Göltenboth R, Grillitsch M, Wiliing R. 1988. On the biochemical systematics of the Bovini. Biochem Syst Ecol 16: 575-579.

Hassanin, A, Ropiquet A, Couloux A, Cruaud C. 2009. Evolution of the Mitochondrial Genome in Mammals Living at High Altitude: New Insights from a Study of the Tribe Caprini (Bovidae, Antilopinae). J Mol Evol 68: 293

Hebert PDN, Cywinska A, Ball SL, deWaard JR. 2003. Biological identifications through DNA barcodes. Proc R Soc Lond B Biol Sci 270: 313-321.

Huelsenbeck JP, Ronquist. 2001. Mrbayes: Bayesian inference of phylogeny. Bioinformatics 17: 754-755. $\square$

Jobb G, Haeseler AV, Strimmer K. 2004. Treefinder: a powerful graphical analysis environment for molecular phylogenetics. BMC Evol Biol 4: 18. DOI: $10.1186 / 1471-2148-4-18$

Kakoi H, Namikawa T, Takenaka A, Amano T, Martojo H. 1994. Divergence between the anoa of Sulawesi and the Asiatic water buffaloes, inferred from their complete amino acid sequences of hemoglobin $\beta$ chains. Z zool Syst Evolut-forsch 32: 1-10.

Kelly RP, Sarkar IN, Eernisse DJ, DeSalle R. 2007. DNA barcoding using chitons (genus Mopalia). Mol Ecol Notes 7: 177-183

Kimura. 1980. A simple method for estimating evolutionary rates of base substitutions through comparative studies of nucleotide sequences. J Mol Evol 16 (2): 111-20.

Knight WJ dan Holloway JD. 1990. Insects and the rainforests of South East Asia (Wallacea). Royal Entomological Society. London. $\square$

Kochar HPS, Appa KBC, Luciano AM. 2002. In vitro production of cattle-water buffalo (Bos taurus-Bubalus bubalis) hybrid embryos. Zygote 10: 155-162

Kwong, S, Srivathsan A, Meier R. 2012. An update on DNA barcoding: low species coverage and numerous unidentified sequences. Cladistics 28: 639-644

Lakra WS, Goswami M, Gopalakrishnan A. 2009. Molecular identification and phylogenetic relationships of seven Indian Sciaenids (Pisces: Perciformes, Sciaenidae) based on 16S rRNA and cytochrome c oxidase subunit I mitochondrial genes A. Mol Biol Rep 36: 831-839

Lydekker R. 1905: A new anoa. Field 106: 378.

Martin AP. 1995. Metabolic rate and directional nucleotide substitution in animal mitochondrial DNA. Mol Biol Evol 12 (6): 1124-1131

Merker S, Driller C, Dahruddin H, Wirdateti, Sinaga W, PerwitasariFarajallah D, Shekelle M. 2010. "Tarsius wallacei: A new tarsier species from central Sulawesi occupies a discontinuous range." Int J Primatol 31 (6): 1107-1122 $\square$

Nei, M. 1987. Molecular Evolutionary Genetics. Columbia University Press, New York.

Perna NT, Kocher TD. 1995. Patterns of nucleotide composition at fourfold degenerate sites of animal mitochondrial genomes. J Mol Evol 41: 353

Pitra C, Furbass R, Seyfert HM. 1997. Molecular phylogeny of the tribe Bovini: alternative placement of the anoa. Evol Biol 10: 589-600.

Rach J, DeSalle R, Sarkar IN, Schierwater B, Hadrys H. 2008. Characterbased DNA barcoding allows discrimination of genera, species, and populations in Odonata. Proc R Soc B 275: 237-247.

Rozzi R. 2017. A new extinct dwarfed buffalo from Sulawesi and the evolution of the subgenus Anoa: An interdisciplinary perspective. Quat Sci Rev 157: 188-2015.

Sarkar IN, Thornton JW, Planet PJ. 2002. An automated phylogenetic key for classifying homeoboxes. Mol Phylogenet Evol 24: 388-399.

Schreiber A, Notzold G. 1995. One EEP, but how many anoas? In: EEP Yearbook 1994/95 Rietkerk F, Brouwer K, Smits S (eds.). EAZA/EEP Executive Office, Amsterdam.

Schreiber A, Nötzold, Manuela H. 1993. Molecular and chromosomal evolution in anoas (Bovidae: Bubalus spec.). Z Zool Syst EvolutForsch 31: 64-79.

Schwartz MK, Luikart G, Waples RS. 2007. Genetic monitoring as a promising tool for conservation and management. Trends Ecol Evol 22 (1): 25-33. 
Setiadi MI, McGuire JA, Brown RM, Zubairi M, Iskandar DT, Andayani N, Supriatna J, Evans BJ. 2011. Adaptive radiation and ecological opportunity in Sulawesi and Philippine fanged frog (Limnonectes) communities. Am Nat 178 (2): 221-240.

Solihin DD. 1994. Peran DNA mitokondria (mtDNA) dalam studi keragaman genetik dan biologi populasi pada hewan. Hayati 1 (1): 1 4. [Indonesian]

Sugiri N. Hidayat N. 1996. The diversity and hematology of anoa from Sulawesi. In: Manansang J, Hedges S, Siswomartono D, Miller P, Seal U. (eds.). Population and Habitat Viability Assessment Workshop for the Anoa (Bubalus depressicornis and Bubalus quarlesi) Report, 22-26 July 1996. Taman Safari Indonesia, Cisarua, Bogor, Indonesia.

Tamura K, Stecher G, Peterson D, Filipski A, Kumar S. 2013. Mega6: molecular evolutionary genetics analysis version 6.0. Mol Biol Evol 30: 2725-2729.

Tanaka T. Solis CD. Masangkay JS. Maeda K. Kawamoto Y, Namikawa T. 1996. Phylogenetic relationship among all living species of the genus Bubalus based on DNA sequences of cytochrome b gene. Biochem Genet 34: 43-45.

Tobe HS. Andrew C. Kitchener. Adrian MT. Linacre. 2010. Reconstructing mammalian phylogenies: A detailed comparison of the cytochrome $\mathrm{b}$ and cytochrome oxidase subunit I mitochondrial genes. PLoS ONE 5 (11): e14156. DOI: 10.1371/journal.pone.0014156

Waugh J, Huynen L, Millar C, Lambert D. 2007. DNA barcoding of animal species - response to DeSalle. Bioessays 30: 92-93.

White CMN, Bruce MD. 1986. The birds of Wallacea. British Ornithologists' Union, London.

Wong EH, Shivji MS, Hanner RH. 2009. Identifying sharks with DNA barcodes: Assessing the utility of a nucleotide diagnostic approach. Mol Ecol Resour 9: 243-256.

Wong EHK, Hanner RH. 2008. DNA barcoding detects market substitution in North American seafood. Food Res Intl 41: 828-837.

Yang C, Xiang C, Qi W, Xia S, Tu F, 2013. Phylogenetic analyses and improved resolution of the family Bovidae based on complete mitochondrial genomes. Biochem Syst Ecol 48: 136-143. 